\title{
Statelessness, forced migration and the security dilemma along borders: an investigation of the foreign policy stance of Bangladesh on the Rohingya influx
}

\author{
Mohammad Sajedur Rahman ${ }^{1} \cdot$ Nurul Huda Sakib ${ }^{1,2}$ (D)
}

Received: 19 September 2020 / Accepted: 5 June 2021 / Published online: 30 June 2021

(c) The Author(s), under exclusive licence to Springer Nature Switzerland AG 2021

\begin{abstract}
Statelessness not only triggers crises within the boundaries of a state, but these crises often spread along borders. The Rohingya refugee crisis, resulting from systematic state atrocities towards a stateless community, has resulted in a massive wave of forced migration to neighbouring Bangladesh. Subsequently, the large number of refugees is exerting enormous pressure on the economy of this developing nation. The crisis can be understood from the perspectives of both human concerns and Bangladesh's traditional security concerns. Furthermore, the COVID-19 pandemic is bringing additional challenges. This study investigates and examines the nature of the dilemma faced by the Bangladesh government in its foreign policy strategy over the Rohingya refugee crisis. It is argued that Bangladesh is facing dual challenges from the national and human security perspectives, and that the regional interests of major players, such as India, China, Russia and Japan, are determining the country's policy stance. It is also argued that the plight of the Rohingya people through their statelessness has become less decisive in the major powers' diplomatic calculations. The findings suggest that Bangladesh should accentuate its efforts to internationalise the issue and engage in a vigilant balancing between the major players for the repatriation of refugees, while, at the same time, exerting bilateral pressure on Myanmar.
\end{abstract}

Keywords Statelessness $\cdot$ Rohingya $\cdot$ Foreign policy $\cdot$ National security $\cdot$ Human security $\cdot$ Forced migration and human rights $\cdot$ Host nation

Nurul Huda Sakib

nhsakib@juniv.edu

1 Department of Government and Politics, Jahangirnagar University, Savar, Dhaka, Bangladesh

2 Department of Government and Politics, Jahangirnagar University, Dhaka, Bangladesh 


\section{Introduction}

Once they had left their homeland they remained homeless, once they had left their state they became stateless; once they had been deprived of their human rights they were rightless, the scum of the earth. Hannah Arendt (2005) The Origins of Totalitarianism (p. 267)

These few words from Hannah Arendt's seminal book The Origins of Totalitarianism closely fit the situation of the Rohingya communities. The Rohingyas have been termed the "most persecuted minority in the world" (United Nations High Commissioner for Refugees [UNHCR] 2018b), given the gross human rights violations and systematic state atrocities experienced by this community in the Rakhine State of Myanmar in the recent past. Bangladesh is currently home to the majority of the Rohingya population, with Kutpalang now the largest refugee camp in the world (UNHCR 2019). The Rohingyas, the largest stateless population in today's world, have no rightful claims to citizenship of Myanmar, the country from which they originate. The state authority of Myanmar has recognised the Rohingyas as "illegal migrants" from Bangladesh to the Rakhine State of Myanmar (Ahmed 2010). The countries in which the Rohingyas have chosen to take shelter (e.g. Bangladesh, India, Malaysia and Thailand) are not signatories to the 1951 Refugee Convention and its 1967 Protocol (UNHCR 1951), with their status and rights as refugees having no legal bindings in these countries. Therefore, they are without the rights of citizens in their home country, and cannot claim refugee rights in the countries to which they are forced to migrate.

The Bangladesh government refers to the Rohingyas as "forcibly displaced Myanmar nationals" (FDMNs). Shamsul Bari (2020) argued that the Bangladesh government has chosen to call the Rohingyas "refugees", using the term as a diplomatic strategy to avoid international pressure to provide them with legal status under international law and, if needed, to retain the flexibility to seek solutions outside the international regime. The diplomatic stance of other countries neighbouring Myanmar, regarding accepting these refugees, can be argued along the same lines. However, the Rohingyas were not a stateless community throughout the history of this country: they were recognised as eligible for citizenship in the first citizenship law of 1948 after independence (Thawnghmung 2014). They had voting rights and Parliamentary members were elected from the community. After General Ne Win's military coup in 1962, the military junta started a series of military campaigns against people of Indian, Chinese and Pakistani origins that turned into a "nationwide immigration and residence check" (Ansar 2020). This xenophobic drive changed the direction of the politics that had accommodated ethnic groups in the country. In 1982, the Citizenship Act was subsequently passed and the Rohingyas were stripped of their citizenship rights. However, they were not totally excluded from political rights. In the 1990 National Election, they executed their voting rights and, in the 2010 National Election, those who had "temporary registration cards" could cast their votes (Human Rights Watch). However, the voting rights of this period could not ensure that the Rohingyas 
would be accommodated in the political system. The treatment of ethnic minorities by the military junta had its historical legacy from the British colonial period, and can be seen as a nation-building failure:

Instead of making meaningful concessions in the process of nation building, successive military governments imposed their visions (or versions) of the union: at times by force, and gradually appeasing the majority Buddhist population, in a process that [led] to brutality across the borderlands, particularly against the Rohingya. (Ansar 2020)

The statelessness problem eventually spread over the borders and compelled the Rohingyas to undertake forced migrations. Several influxes of Rohingyas to Bangladesh from Myanmar can be traced. However, the exodus that began in March 2017 due to mass atrocities by the Myanmar state was unprecedented. The United Nations (UN) termed the atrocities as a "textbook example of ethnic cleansing" (United Nations [UN] 2017), with these actions forcing over 700,000 refugees into Bangladesh. The Bangladesh government, on humanitarian grounds, has expended significant efforts to accommodate all these refugees in different refugee camps. In the 1990s, the country had continued with its policy of accommodating refugees when many Rohingya refugees took shelter in Bangladesh.

Consequently, the large numbers of Rohingyas have become an economic concern for this developing country. Furthermore, we argue that the exodus of Rohingyas from Myanmar has created worries for Bangladesh on both traditional territorial and human security grounds. Our analysis shows that statelessness-induced crises cannot be seen as a state's internal issue: they bring many challenges to host countries from the security perspective. This study investigates and examines the nature of the challenges faced by the Bangladesh government on foreign policy strategy over the Rohingya refugee issue, using this crisis as a case of stateless people. In doing so, the study systematically inquires about the challenges faced by the Bangladesh government in dealing with the large-scale arrival of Rohingya refugees since August 2017. The study also investigates the security dilemmas faced by the Bangladesh government. Based on the study's arguments and analysis, policy recommendations are formulated as discussed in the following sections.

\section{Statelessness, human rights and forced migration: a conceptual understanding}

In this age of the nation state, the state has become a representative identity for human beings. The world system is a web-of-states relationship, with citizenship a requirement for the existence of order. The Universal Declaration of Human Rights (1948) entitled every person with the right of nationality. According to Article 15 of the Universal Declaration, "[e]veryone has the right to a nationality" and "[n]o one shall be arbitrarily deprived of his[/her] nationality" (UN 1998). However, through some people being left stateless, they are denied this right of being human. Hannah Arendt (1976), who herself was a stateless refugee for 18 years, raised the question 
of the plight of stateless persons who are deprived of basic human rights. Only a member of a nation state can enjoy legally protected civil, political, or social rights as it is the state that ensures those rights. Therefore, "the rights to have rights", or membership of the political community, is crucial to enjoying human rights. Arendt (1976) rightly pointed out:

The Rights of Man, after all, had been defined as 'inalienable' because they were supposed to be independent of all governments, but it turned out that the moment human beings lacked their government and had to fall back upon their minimum rights, no authority was left to protect them, and no institution was left to guarantee them. (p. 291)

Although Arendt originated the idea of "the rights to have rights" in her work in the 1940s, in the new millennium, the concept has become influential in academia in understanding stateless people's problems (DeGooyer et al. 2018). Giorgio Agamben (1998) is also an influential thinker on the question of stateless people. He defined their lives as homo sacer, in reference to the people of ancient Greece denied a place in court, describing their lives as bare lives in which biopolitics were denied. Therefore, the state is a crucial apparatus through which a human being can enforce his/her inalienable rights, just as the state enforces rights within a political boundary. Seyla Benhabib emphasises the point that these rights can be enforced through the international community and by recognition of the universal status of the personhood of each (Benhabib 2014, cited in DeGooyer et al. 2018). In today's world, the right of every individual to be a citizen of a state is enforced in major international conventions. ${ }^{1}$ In this context, the right to not be stateless (i.e. the right to a nationality) can be recognised as a fundamental human right (Weissbrodt and Collins 2006). Although international laws guarantee the right to nationality, statelessness remains a global problem that can be termed a "forgotten human rights crisis" (Kingston 2013). However, national interest is the core factor in determining foreign policy strategies in international politics, with the sovereign state's purposes maintained by "patterns of defence arrangements and international trade", not by the upholding of human rights (Hill 1989, p. 10).

Since security issues in international relations became multidimensional after the end of the Cold War, the policy stances of nation states are influenced by various actors (Buzan 1997). Different schools of thought (idealist, liberalist or constructivist) emphasise moral issues in foreign policy; however, security and national interest are still influential tools used to understand the foreign policy stances of nations in the international system (Burchill 2005). Political realism, as defined by Hans Morgenthau (1993), is for the maximisation of "interest in terms of power" by the nation state and, for that purpose, "universal moral principles cannot be applied to

\footnotetext{
1 David Weissbrodt and Clay Collins examine the major international conventions of human rights and identify the rights of citizenship as a common component of the conventions. The treaties they examined comprised: the International Covenant on Civil and Political Rights, the Convention on the Rights of the Child, the Convention on the Elimination of All Forms of Discrimination against Women, the Convention on the Nationality of Married Women, the $9^{\text {th }}$ Convention on the Reduction of Statelessness and the Convention Relating to the Status of Stateless Persons (Weissbrodt and Collins 2006).
} 
the actions of states" (p. 5). Neo-realism's structural emphasis on the anarchic system of international politics defines the ultimate political stance of a nation that "is not for power but for security", as described by neo-realist founder Kenneth Waltz (1988). Nevertheless, the idea of security has changed (from territorial security to that of human, economic, environmental, etc. security) in the globalised world system, and realism seems insufficient for analysing complex international politics in today's world. However, Stephen M. Walt (2018), in an essay published in Foreign Policy, claimed that realism is still an effective tool through which to understand state policy:

if you think like a realist, you're likely to be sceptical about the ambitious schemes that idealists keep dreaming up to bring an end to the conflict, injustice, inequality, and other bad things. Striving to build a safer and more peaceful world is admirable, but realism reminds us that the ambitious efforts to remake world politics always create unintended consequences and rarely deliver the promised results.

One of the consequences of statelessness is forced migration. As stateless people are a marginalised community, they need special care from host nations. However, recent research on the Rohingya expatriate situation concentrates on the political causes of the problem, or on human security, the health crisis, etc. In contrast, Imtiaz Ahmed (2010), Thomas K. Ragland (1994) and David Scott Mathieson (2009) focus on the Rohingya problems of violation of their human rights, their statelessness, critical deportation issues and other related crises in border areas. Recent articles also broadly focus on the Rohingyas' humanitarian crisis (Lewis 2019); the identity, citizenship crisis and systematic dispossession, occupation, and destruction of an ethnic group (Maclean 2019; Kipgen 2019); health concerns, mental health and trauma (Villasana 2017; Riley et al. 2017; Chan et al. 2018). However, few comprehensive studies on the Rohingya people have examined the problem from the perspective of the foreign policy stance of host countries. In assuming this to be a research gap, this study investigates the challenges on foreign policy grounds of the host nation when facing the forced migration of refugees.

\section{Methodology}

Two data collection methods were employed for this qualitative research. The nature of the study required a combination of textual analysis and in-depth interviews, which is common in qualitative research. Creswell (2012) argues that research arguments are validated by data collected through various sources. Similarly, Halperin and Heath (2012) emphasise the use of various sources of data for better research output. In this research, we sought to adhere to our main research questions. Consequently, both document analysis and in-depth interviews were employed to analyse the following key research questions: what are the challenges faced by the Bangladesh government regarding foreign policy strategies over the Rohingya refugee issue? What type of security dilemmas are faced by the Bangladesh government? 
And, in addressing them, what are the dimensions of Bangladesh's foreign policy stance?

First, the study undertook an extensive document analysis and literature review. A thorough examination was performed using the following keywords: "statelessness", "Rohingya", "foreign policy", "national security", "human security", "forced migration \& human rights" and "host nation", relating to the Rohingya issue, thus aligning with our research questions. This inquiry gave us a large amount of documents from which we systematically chose relevant papers relating to our research theme. These documents and studies in the literature have been used systematically in this study, depending on the theme and research questions. The definitive intention of this inquiry was to develop stronger coherence with the in-depth interviews to support our research findings.

Qualitative research often lacks rigorous analysis if conducted without in-depth interviews with relevant stakeholders. Empirical research, such as the current study, needs a detailed analysis to understand the real picture. Therefore, most of our findings were generated from in-depth interviews with multiple stakeholders who were actively engaged with the Rohingya community. In total, 25 in-depth interviews were conducted in the entire study asking questions relating to our research questions. Interviewees were contacted through phone, email or personal communication. Stakeholders were mainly academic researchers, practitioners, government employees, aid workers, host community members and local leaders. We also consulted with some members from the Rohingya community asking questions related to human security issues, their current satisfaction and the role played by the Bangladesh government as it related to them. Interviews lasted from 10-40 min depending on their answers and expertise. Before starting the interview, we assured each interviewee that the interview was anonymous, that their information would not be disclosed at all and that the interview data would be used for academic research purposes. We strongly maintained these protocols for research integrity and obtained the best input from each interviewee, who might otherwise fear expressing his/her views on such a sensitive issue. Data from these in-depth interviews were coded relating to our theme and used in the research where needed. Documents and news articles gathered from secondary sources were later integrated with the interview findings to make a stronger argument.

\section{The Rohingya Exodus and Bangladesh's response}

Myanmar's Citizenship Act of 1982 which denies citizenship to the Rohingyas is undoubtedly the root cause of the Rohingya crisis. The Rohingya people have lived in the Arakan State of Myanmar for generations, which is called the historic home of Muslim Rohingyas (Farzana 2017). The Rohingya people are assumed to have been present in the region since the arrival of Arab traders through the Bay of Bengal in the eighth century (Rüland 2017). However, that claim is overruled by the majority Buddhist communities who consider the Rohingyas to be illegal immigrants from Bangladesh (Chan n.d.). The idea of "national races" or taingyintha plays an instrumental role in identifying and excluding minorities from the state priorities of 
Myanmar. The taingyintha idea can be traced back to the 1920s, but it became dominant in political discourse after the 1960 s, providing the basis to deny political rights to minorities (Cheesman 2017). The controversial 1982 law stripped the Rohingyas of equal access to citizenship and rendered them stateless by excluding them from the list of 135 recognised national ethnic groups. They were also firmly excluded from freedom of movement, and freedom of access to education and employment, and were subject to the arbitrary confiscation of property and forced labour (Human Rights Watch 2000b). The violation of citizens' rights and forced labour are heard in the voice of this Rohingya woman:

The army made villagers go to work on the Tang Ma Road. I had to go and break stones that would be used for the road surface. The army did not pay us or give us any food. I had to work in seven- to fifteen-day shifts from seven in the morning until eight in the evening. I couldn't go home, so I had to sleep in the army camp. Each time, the army would come to collect twenty to forty villagers to go work. The village headman made the lists, and if we did not go, we could be arrested. I worked on this project from 1997 to early 1998. Just before I left, I was working for the state-owned Sukrasa Sugar Mill in Kaung Daung. I had to cut sugar cane and then carry it to the trucks. Here, again, I worked seven- to fifteen-day shifts with no pay or food provided. (Human Rights Watch 2000b)

Only an estimated 40,000 Rohingyas were able to acquire citizenship in the region after the Citizenship Act of 1982 (Forty Rights 2014). It was estimated that two million Rohingyas lived in Myanmar, of which approximately 800,000 lived in northern Rakhine State (Farzana 2017). The UNHCR also assessed that over 800,000 persons remained stateless/without citizenship in the northern part of Rakhine State (UNHCR 2015), with most of the population forced to migrate to Bangladesh due to the large-scale killings, rapes and human rights violations performed by state authorities. As estimated by the UNHCR, as of December 2018, 907,199 persons have been forced to migrate to Bangladesh (UNHCR 2018a).

Although forced migration to Bangladesh intensified following the 1982 citizenship ban, the exodus can be traced to before that time. The first influx of Rohingyas was recorded in 1784 after the fall of Arakan State. Many of these refugees never returned to Arakan but settled and became integrated with the local community in the region (Danish Immigration Service 2011). Since then, six influxes of Rohingyas to Bangladesh have been witnessed. The second influx of 22,000 people was recorded in 1942 when Japan invaded the area during World War 2. The third influx of approximately 200,000 occurred in 1978 when General Ne Win conducted a screening operation called Operation Dragon King (Danish Immigration Service 2011). The next two influxes (the first from 1991 to 1992, the second in 2012), with a significant number of refugees taking shelter in Bangladesh, were the consequences of the 1982 citizenship ban that subsequently created a clear division in the region. Finally, in 2017, the worst humanitarian crisis occurred when the state machinery in Myanmar started a systematic mass series of atrocities towards the Rohingyas, helped by the local Rakhine communities, and approximately 700,000 people fled to Bangladesh to save their lives. Some media (e.g. Time magazine) described this 
as the emergence of Buddhist terror as Buddhist monks backed the conflict (Beech 2013). The atrocities included "a pattern of widespread human rights violations, including rape, gang rape, and other forms of sexual violence against women and girls, murder, torture, looting and the burning of homes and villages" (UN 2018). It is estimated that approximately 25,000 Rohingyas were murdered and 19,000 Rohingya women and adolescents were raped during the conflict (The Daily Star 2018), with 392 Rohingya villages demolished by torching all settlements to the ground [Human Rights Watch 2019]. A Rohingya leader in the camp (the majhi) explained the situation during an interview:

Who wants to leave his/her own country? We didn't have any option apart from crossing the border. Our sisters and mothers were raped, villages were burnt, men were brutally killed. We are also human, not animal. Tell me what choices we have? We are grateful to the Bangladesh government for sheltering us. (pers. communication, 25 July 2019)

Subsequently, in November 2017, state authorities from the governments of Bangladesh and Myanmar signed an "agreement" to repatriate Rohingya refugees to their native Rakhine State within two months, but without consulting either the UNHCR or any Rohingya refugee communities. The controversial "agreement" proved to be ambiguous and impracticable (The Washington Post 2018). Two attempts to repatriate refugees failed due to Myanmar's insincerity in meeting the core demand of granting recognition to the Rohingyas (The Daily Star 2019b).

After the 1978 influx, bilateral diplomatic initiatives with Myanmar were successful, at that time, in the repatriation of refugees. Following that case, Bangladesh also sought a bilateral repatriation deal, with China's mediation, after the 1992 influx, but without consulting either the UNHCR or the Rohingya refugees (Human Rights Watch 2000a). However, this time, the Citizenship Act of 1982 was in effect, Myanmar added some conditions to prove citizenship upon return (The Daily Star 2017) and the deal was unsuccessful. Even though some refugees were returned to their homeland, approximately 300,000-500,000 refugees never returned. In the case of the 2017 repatriation, Myanmar apparently wanted to follow the 1992 repatriation deal as a reference (Liton 2018), but is seeming to delay the bilateral diplomatic procedure. With this backdrop, it can be argued that, if the current crisis becomes prolonged as it has in the past, the repatriation of refugees can become stuck in complex geopolitics and diplomatic calculations.

\section{How does statelessness create problems for Bangladesh?}

Denial of citizenship and, consequently, the statelessness of the Rohingya minority began as an internal problem of the Myanmar state. However, the problem does not end at the Myanmar boundary but has instead spread across borders, becoming a serious concern for Bangladesh at both internal and international levels. Providing such large numbers of people with shelter and humanitarian support, even with help from the UNHCR and international communities, is a vital challenge for the country. Furthermore, it has become a serious security concern, both from traditional 
and non-traditional security perspectives, for Bangladesh. In the following section, our discussion shows how the Rohingya problem jeopardises Bangladesh's national security profile, while, at the same time, undermining the country's human security prospects.

\section{The Rohingyas as a national security threat for Bangladesh}

Bangladesh is surrounded by neighbouring India on three sides and shares only $271 \mathrm{kms}$ of border with Myanmar. The geopolitical context and the nation's commitment to and strategy, as a small state, of promoting peace with its neighbours have significantly motivated the country to adopt friendly foreign policy goals with her two neighbours. After decades of isolation, the opening-up of new business opportunities with Myanmar has considerably encouraged Bangladesh to establish a close relationship between the two countries. However, the relationship between them was not seen to be very warm in the recent past. Moreover, owing to the isolation policy, no normal regular communication existed between the two nations who only had a ceremonial diplomatic relationship.

The two nations have border issues, including exchanges of fire over a controversial dam project on the Naaf River in 2001 (British Broadcasting Corporation [BBC] 2001). In 2008, the two nations were involved in a dispute over gas exploration in the sea with both sides sending naval ships (The Guardian 2008). Therefore, tensions in the borderlands are not unusual between the two countries to which their military rivalry is added. In 2016, Bangladesh purchased two submarines from China at US\$203 million (The Times of India 2016) and, in response, Myanmar bought torpedoes from India. Myanmar is set to obtain a Russian-made Kilo-class dieselelectric attack submarine from India to enter the naval competition (Panda 2019). In terms of military strength, these two nations hold comparable military power. In this context, it can be argued that the Rohingya crisis can evolve into a significant concern in the context of traditional/territorial security for Bangladesh. Moreover, an attempt by Myanmar to undertake construction in no man's land on the border is seen to violate international laws (The Daily Star 2019a). Therefore, tension due to the Rohingya crisis can hamper the relationship between the two nations and create confidence-building barriers between the parties.

The Rohingya refugee crisis can also be seen as a major threat for Bangladesh in terms of generating militancy along the border. Although Bangladesh has had significant success in combating militancy in the recent past, the nation has not yet passed beyond its threat. The nation has faced several militancy attacks in the past decade, with these attacks assumed to have global militancy linkages. Although most militancy organisations in Bangladesh are viewed as homegrown organisations, global jihadism has been recognised as their instigator. In August 2005, the country trembled as Jamaat-ul-Mujahideen Bangladesh (JMB) set off approximately 500 bomb 
explosions at 300 locations in 63 of Bangladesh's 64 districts to show its strength. Most of JMB's top leadership were tried and later executed, and the organisation now seems dispersed and weakened. The holy artisan massacre ${ }^{2}$ and killing of bloggers $^{3}$ have exponentially jeopardised the country's image, becoming national security concerns. The nation has shown her strength in combating militancy, with its law enforcement agency exhibiting maturity to dealing with the problem. However, the risk of new breeds of militancy has not disappeared (International Crisis Group 2018). Against this backdrop, the Rohingya issue can be seen as a security threat to Bangladesh. An academic interviewed for this research elaborated on this point in the following words:

Rohingya people living in Bangladesh are in severe crisis. They have limited work right[s] and freedom of movement. Therefore, it is very easy to divert them into ill motives. There are both local and international players ... ready to take this opportunity and divert them into an act of terrorism. (pers. communication, 13 September 2019)

The atrocities faced by Muslim Rohingyas in Arakan State may instigate distress, and the global network of Islamic militancy could use this sentiment for their purpose. In 2002, a religious riot occurred in Ramu in Chittagong, with Buddhist communities facing arson and religious uproar originating from a Facebook status by a young Buddhist, with it alleged that Rohingya refugees were involved in the violent attack (Ahmed 2012). The Rohingya refugee crisis could therefore instigate multidimensional risks for Bangladesh. The Arakan Rohingya Salvation Army (ARSA) could be seen as a significant threat as its work targets refugees and could undermine hard-earned success in anti-militancy actions (Bashar 2017). al-Qaeda-backed organisations and the banned outfit, the Harkat-ul-Jihadi- Islami (HuJI), are alleged to be actively working in the area (Rahman 2010). In a newspaper report, it was identified that JMB recruited 40 members from the Rohingya to launch "targeted killings" and terror attacks in Cox's Bazar during New Year celebrations on 31 December 2018; however, the police arrested some of the "kingpins" (Dhaka Tribune 2018). From a traditional security viewpoint, the spread of militancy is a significant challenge for Bangladesh.

\section{Human security threats and the Rohingyas}

Bangladesh has achieved remarkable economic success over the years. The country, once called the "basket case" nation, has sustained robust economic growth of $6.7 \%$ of gross domestic product (GDP) per year on average. Bangladesh was officially promoted to the status of a lower-middle-income country in July 2015, with a gross

\footnotetext{
${ }^{2}$ Five militants, claiming to be linked to Islamic State (although Bangladesh police reported that they were from a homegrown outfit), stormed Holly Artisan Bakery and killed 29 people, including 20 hostages (18 foreigners and two locals). Also killed were two police officers, two bakery staff and the five gunmen.

${ }^{3}$ Several online activist and secular bloggers were killed in Bangladesh by Islamic militants, with most of these trials still under way.
} 
national income (GNI) per capita of US\$1,046 (World Bank 2018a). Bangladesh has also had outstanding success in poverty reduction, with the country's level of poverty declining from $44.2 \%$ in 1991 to $13.8 \%$ in $2016 / 17$, based on the international poverty line of US\$1.90 per person per day (World Bank 2018a). Life expectancy, the literacy rate and per capita food production have increased significantly at a similar pace (World Bank 2018b). However, many people still live below the poverty line. To sustain her position as a lower-middle-income country, Bangladesh needs to invest more in infrastructure, the energy sector and human resources (HR) development. As a small country with a land area of $147,570 \mathrm{~km}^{2}$ and a population of 161.4 million, Bangladesh faces a struggle to achieve food security and ensure human development goals. For a country transitioning to middle-income status, incurring the enormous burden of a million refugees presents a direct challenge to her human security goal. Bangladesh is also projected to be one of the countries severely affected by the impact of global climate change, which poses a serious threat to her human security profile.

A million Rohingya refugees are now assumed to be living in Bangladesh, of whom many are unregistered, with it extremely difficult to recognise them, owing to their proximity to local Bengali inhabitants. The country is working alongside the UNHCR, other UN organisations, non-governmental organisations (NGOs) and other donor organisations. According to Steven Corliss of the UN refugee agency, UNHCR, in Bangladesh:

It is a dilemma because the overt policy is return, while the objective reality is that return will be extremely difficult ... The situation is untenable: environmentally, socially and economically. (Solomon 2019)

Accommodating over a million Rohingyas is a mammoth task for Bangladesh. In 2019, only US\$302 million was received for the Joint Response Plan (JRP), even though the requested amount was US\$920.5 million (International Crisis Group 2019). Therefore, a significant gap is evident in the funds received to maintain humanitarian support for so many refugees. The BBC Bangla report that the money flow has been declining from donors (Hossain 2019). The Bangladesh Government has already spent Bangladeshi taka (BDT) 2500 crores (one crore equals 10 million) (approximately US\$296 million) supporting the Rohingya refugees, a huge expense for the developing nation (Hossain 2019). In an area that is already poverty prone, these refugees are increasing the burden of the ongoing poverty situation. From the first arrivals, the cheap labour of Rohingya labourers has negatively impacted on the labour situation of local labourers (Rahman 2010). The Rohingya influx has reportedly caused a $14.3 \%$ wage reduction for all labourers among the host community in Teknaf, Cox's Bazar (The Daily Star 2019d). In that locality, the prices of daily essentials have risen by $50 \%$, while, at the same time, wages of day labourers have decreased after the refugee influx (The Daily Star 2019d). Over 2500 households have fallen below the poverty line of the local community. The influx has also had a heavy toll on the environment in the area. It is estimated that 5500 acres of reserved forests and 1500 hectares of wildlife habitat have been destroyed due to the pressure of such a large population. The cost of environmental damage to 2018 was assessed 
as approximately BDT 1865 crores (approximately US\$215 million) (The Daily Star 2019d).

Large numbers of refugees could become a serious threat to Bangladesh's internal security and social harmony. The law enforcement agencies highlight the involvement of Rohingya people in different criminal activities, thus putting at risk the lawand-order situation in the Chittagong region (pers. communication, 28 July 2019). The humiliation, deprivation and atrocities with which they have been faced are thought to be the deep causes for Rohingya involvement in criminal activities. From the beginning of the influx, the illegal small arms trade, a flourishing business along the border, has been a security concern for Bangladesh (Rahman 2010). Recently, Yaba Business has become a lucrative venture in the area, with the Rohingya people allegedly involved in the business. Criminal activities, such as theft and looting, are also noticeable among the community. To date, 31 refugees have been killed in different clashes. At the same time, 1088 persons have been accused in 471 cases, with 368 cases related to narcotics (The Daily Star 2019).

Migration to Malaysia is a dream for many poor Rohingyas, as well as for some Bangladeshis. Going to Malaysia in small boats using the sea route was mainly launched by Myanmar nationals: later, many Bangladeshi nationals were involved in the risky journey. Many people died on the way due to the lack of food and water at sea. Moreover, young female refugees have also been at risk of sex trafficking, with many ending up in the sex markets of India and different Middle Eastern countries (Rahman 2010). These issues are serious concerns for Bangladesh's internal security. Moreover, having Rohingya refugees take up a Bangladeshi passport and then travelling to other countries is also a major security concern for the country. During an interview with asylum seekers in Australia, one Rohingya refugee mentioned that:

I came to Australia by boat from Teknaf with the help of Bangladeshi brokers. There were many Bangladeshi people with us on the boat too. We were almost dying before the Australian Coast Guard rescued us. Now I am here as an asylum seeker and working hard to bring my wife who is in the refugee camps in Bangladesh. Soon, I will get Australian citizenship and then I will bring my family from Bangladesh. I have already contacted some brokers and they assured me that they will manage a Bangladeshi passport for my wife. (pers. communication, 26 December 2018)

These words from the Rohingya refugee denote the Rohingyas' painful reality, as well as the involvement of stakeholders who are causing security threats for Bangladesh. Many locals in Cox's Bazar, Bangladesh, are engaging in the human trafficking business that motivates these people to risk seeking asylum. They also maintain strong networks with many corrupt government officials for passport and relevant documents (pers. communication, 14 September 2019). 


\section{Balancing the Major Powers: Bangladesh's Foreign Policy Stance}

The Rohingya crisis has brought a dual concern to Bangladesh: how can the interests of the two major powers, China and India, be balanced? Both rival Asian giants have strategic interests and stakes in Myanmar: they have also allegedly backed the Myanmar authority after the Rohingya refugee crisis. For China, Myanmar can open new access to the ocean through Yunnan Province. Through the Belt and Road Initiative, China is planning to invest US\$7.3 billion, which includes the development of the Kyauk Phyu Special Economic Zone and a deep seaport in the Bay of Bengal (Taufiq 2019). On the other hand, India, in its Act East policy, emphasises working with Myanmar to maintain stability in the north east regions where it shares a common border of $1643 \mathrm{~km}$ with Myanmar and to counter Chinese influence in the area (Taufiq 2019). India has a substantial investment in infrastructure and power and is constructing the seaport in Myanmar. Therefore, it is apparent that strategic interests and untapped economic potential are shaping the role of the two major powers in the Rohingya refugee crisis.

Both China and India are important for Bangladesh's development aspirations. Historically, China has been a close ally to Myanmar, with its military government relying on the Chinese bloc in the country's isolation stage. As a permanent member of the UN Security Council, China has veto power, which is a determining factor for Bangladesh's stance on the Rohingya case to internationalise the problem. Nevertheless, Bangladesh has economic interests in China and has sought to maintain a warm relationship between the two countries. China has proposed US\$24 billion as foreign credit to build power plants, a seaport and railways for the nation (Bangladesh Today 2016), and many Chinese-supported projects are currently being constructed in Bangladesh. On the other hand, India is one of Bangladesh's most important development partners. India helped Bangladesh in its War of Independence and presented Bangladesh's Awami League government with historic ties between the two neighbours. India has also proposed a credit line of US\$2 billion for Bangladesh (Bangladesh Today 2016).

Furthermore, these two countries are Bangladesh's largest trade partners. Economic diplomacy is the central focus of a developing country to sustain its growth, and this plays a significant role in defining the country's foreign policy. It cannot be denied that Bangladesh is surrounded by India, and that India has a strong influence on the nation's political discourse. Moreover, India has become an emerging player in the changed world order. Furthermore, Russia, described as a "friend in need" of Myanmar (Lutz-Auras 2015), has economic and strategic interests in Myanmar with long historic ties. Russia is reportedly one of the countries to sell arms to Myanmar after the 2017 mass Rohingya exodus (The Washington Post 2019). China and Russia also opposed a UN resolution just after the atrocities against the Rohingya people that would have allowed aid workers to access the area, repatriation of the refugees and the granting of their citizenship rights (The Guardian 2016). Thus, it is difficult for Bangladesh to handle the Rohingya issue owing to the need to establish and maintain a tough balance between the major powers within complex strategic and economic contexts. Moreover, Bangladesh needs to consider the international 
context and world order. Khan and Ahmed (2019) argue that the inherent weakness of the UN in light of its dependency on the five permanent members of the UN Security Council for any intervention in humanitarian crises impede the resolution of this problem. Little is left in such an international setting in the hands of a country like Bangladesh to diplomatically pursue the big players to intervene in the situation.

Moreover, the recent Rohingya influx took place in 2017 before Bangladesh's scheduled National Election. The Awami League government did not take the risk of pressuring India and China on the refugee issue for fear of destabilising the status quo before the election. Moreover, giving shelter to Muslim Rohingyas received enormous recognition for Prime Minister Sheikh Hasina, which helped her Awami League party to regain popularity which had been declining among Bangladeshi citizens. The National Election held in December 2018 has been described as an election of a hybrid regime with a low turnout within a controlled political mechanism (Riaz 2019), with the regional status quo possibly helping the Awami League government to regain power. It should also be mentioned that the region is projected to be a new hub of economic activities, and that many financial activities have started. Bangladesh is also aiming to grab untapped potential. With so many calculations, Bangladesh took the path that avoided hard measures, but instead pursued the two influential nations to convince Myanmar of the need for fruitful repatriation. According to one academic:

I really doubt Bangladesh's capacity to handle [the] issue as it become[s] an international problem rather than a regional [one]. There is a lot [of] development plan[s] going [on] in the region and both India and China want to dominate and get maximum interest. Therefore, I think the whole ethnic cleansing is a well-executed long-term plan. Even moving the Rohingyas into Bhashan Char is strategically not a bold decision as it will make the issue more complex, and repatriation might [become] stuck nowhere. (pers. communication, 5 December 2019)

His claim is becoming more relevant as time passes. Other countries, such as Japan despite its liberal values, also have economic interests in the Rakhine State of Myanmar and allegedly remain indifferent to the plight of the Rohingya people. Japan has abstained from all Myanmar-related resolutions at the UN and has refused to recognise the term "Rohingya", although "Muslims in Rakhine State" has been considered to sound more neutral (Kasai 2019). Japan's new initiative, the Free and Open Indo-Pacific (FOIP) strategy with the United States (US) designed to curb China's influence in the area, might be responsible for Japan's stance on the Rohingya refugee issue. ${ }^{4}$ However, in a recent move, Japan has expressed its interest in performing the role of mediator between Bangladesh and Myanmar to ensure immediate smooth repatriation of Rohingya refugees (The Daily Star 2019c). Bangladesh therefore needs to emphasise the careful balancing of the major powers in achieving successful repatriation measures for the Rohingya refugees.

\footnotetext{
${ }^{4}$ For more about FOIP, see Kei Koga, Japan Free and Open Indo-Pacific (FOIP) Strategy, Contemporary Southeast Asia, Vol. 41, No. 2 (August 2019), pp. 286-313.
} 


\section{The creeping Rohingya crisis: new developments}

Bangladesh's weak foreign policy stance became visible when Rohingya refugees were observed to be entering Bangladesh from other countries. At least 1300 refugees crossed the border from India to Bangladesh in January 2019 (Dhaka Tribune 2019a). This happened when India started procedures to repatriate Rohingya refugees in India to Myanmar, and these refugees fled to Bangladesh, fearing that they might not be returned to their homes but instead to camps managed by the authorities. Moreover, Saudi Arabia has recently been thinking of pushing back some Rohingyas to Bangladesh: these people had reached Saudi Arabia through Bangladesh, allegedly by taking out Bangladeshi passports (Bangladesh Today 2019). Bangladesh has a close relationship with Saudi Arabia and recently joined a Saudi-led military coalition, although this step did not prevent Saudi Arabia from the move to return the Rohingya refugees.

In fact, after two failed attempts of refugee repatriation to Myanmar, this raises the question: will Bangladesh become the permanent destination for the Rohingyas? The last attempt to repatriate refugees on 24 August 2019 involving nearly 300 families failed as the authorities failed to convince the refugees that their return would be safe (The Guardian 2019). The refugees demanded citizenship from Myanmar as a guarantee before their return, with thousands of refugees demonstrating for citizenship in their camp premises the day after the failed repatriation (BBC 2019). China is believed to have had a role in pursuing the Myanmar authorities in this repatriation process. It has been reported that an official from the Myanmar Embassy and two officials from the Chinese Embassy were present on the occasion (Dhaka Tribune 2019b). In a Bangladeshi newspaper report, it was termed a "diplomatic drama" between Myanmar and Bangladesh on the repatriation of Rohingya refugees, and that Myanmar might face a hard time in the upcoming UN General Assembly in September 2019 (Ejaz 2019). In this context, the question can be raised regarding the sincerity of the Myanmar authorities in their repatriation of stateless refugees: is this instead a strategy for prolonging the crisis?

One good effort was recorded when the Gambia, a small West African nation, filed a lawsuit on 11 November 2019, with full support of the Organization for Islamic Cooperation (OIC), against Myanmar at the International Court of Justice (ICJ) for perpetrating genocide on ethnic Rohingya Muslims (The Voice of America [VOA] 2019). Bangladesh has donated US\$500,000 to the OIC fund to support the Gambia's legal initiative (Dhaka Tribune 2020). The ICJ has ordered Myanmar to take urgent measures to save the Rohingya minority, with this having crucial legal implications as it can be an instrument for exerting diplomatic pressure on Myanmar. One analyst has expressed the view that fear of US and European sanctions can pressure Myanmar and ensure some justice for the Rohingyas (Ciorciari 2020). Furthermore, aid agencies are exerting pressure on the Bangladesh government on the issue of moving the Rohingyas onto Bhasan Char, a remote island in the Bay of Bengal. Bangladesh is planning to relocate a segment of the refugees to this island to lessen the burden of the large numbers of the Rohingya population in one locality, but the government is being heavily criticised by aid agencies for this move to 
confine the refugees to an unsafe island (British Broadcasting Corporation [BBC] Bangla 2021). The US\$350 million project is called Ashrayan (Shelter)-3 and is being implemented by the Bangladesh Navy on an area of 13,000 acres of land, with the government mainly focussed on the deteriorating security situation and environmental degradation in the area of Cox's Bazar (Bhattacharyya 2021). In total, 18,334 refugees have been shifted to the island in six phases, with the refugees expressing their satisfaction about the camp facilities to foreign envoys who visited the island on 3 April 2021 (Dhaka Tribune 2021).

In addition, the COVID-19 pandemic has brought more challenges to Bangladesh. The first death of a Rohingya refugee was recorded on 31 May 2020: with $60,000-90,000$ people living in each square kilometre, this has the potential to create a humanitarian disaster in the Cox's Bazar area (Al Jazeera 2020). It is estimated that Bangladesh's economic growth could decline to $2.5 \%$ due to the pandemic, which is the lowest in 25 years (The Daily Star 2020), and that the unavoidable burden of large numbers of Rohingya refugees could fuel economic hardship in Bangladesh.

\section{Concluding remarks: the way forward}

Statelessness/denial of citizenship has undoubtedly played the most crucial role in the systematic ethnic cleansing and eventual forced migration of thousands of stateless Rohingyas from Myanmar to Bangladesh. Based on the current study, this paper argues that an internal crisis of statelessness of a community within a country creates challenges to other countries, spreading the problem across borders. Bangladesh, a developing nation, has suddenly felt the responsibility to feed and ensure the basic requirements for a million people who are not its citizens. Bangladesh, as a host nation, is facing a dual crisis from traditional security and human security perspectives, intensifying the nation's foreign policy challenge. The Rohingya refugee crisis is described as "a time bomb" waiting to explode, which will not only affect Bangladesh but the whole region in terms of security concerns (Bari 2020). Our study findings suggest that national interests play a significant role in shaping foreign policy stances of nations and that moral stances from the major players seem less influential in intervening in the crisis. China, India, Russia and Japan have their own national interests in Myanmar that are shaping their response to the crisis.

Although Bangladesh's response has mostly been on humanitarian grounds, as a host nation, it is focussing on the repatriation of the Rohingya refugees from a national interest perspective and owing to security concerns. Bangladesh came up with the term "forcibly displaced Myanmar nationals (FDMNs)" for these refugees, as Myanmar is not a signatory of the 1951 Refugee Convention or of its 1967 Proto$\mathrm{col}$, which could be seen as a diplomatic stance to channel away the responsibilities of such large numbers of refugees. However, the term "forcibly displaced Myanmar national (FDMN)" is not recognised in any international document and has failed to exert pressure on Myanmar through legal procedures. It is the rightful claim of the stateless Rohingyas to repatriate to their homeland where they have belonged for many years, with this backed by international norms and protocols. Bangladesh 
stands the risk of becoming the permanent home of millions of Rohingyas if successful repatriation fails and the statelessness problem is not resolved in their home country.

With this backdrop, what can Bangladesh do to achieve successful repatriation of the Rohingya refugees, while ensuring their safety and dignity? The nation should reassess the situation and speed up the diplomatic machinery from a "go slow" policy to handle this humanitarian crisis. Bangladesh must rethink its policy stance and should emphasise solving the problem internationally by creating pressure at every possible level. The large numbers of Rohingya refugees can be an instrumental tool used by the international community to pressure Myanmar, as no other nation has received so many refugees in such a short time.

Moreover, the unprecedented atrocities and human rights violations by the state authorities of Myanmar have received significant media attention and are well documented by international organisations. Therefore, Bangladesh should uphold the situation of the grievances of the stateless Rohingyas in every forum in the international arena, including UN organisations, international non-governmental organisations (INGOs), donor organisations and civil society organisations. Bangladesh should internationalise the problem at every possible level, with forming an international commission a possible way to exert pressure on Myanmar. Although bilateral problem solving with Myanmar is seen as ineffective, international arbitration can be a useful instrument (United News of Bangladesh [UNB] 2019); Bangladesh should employ both. The Rakhine Advisory Commission (RAC) report led by the former UN Secretary-General Kofi Annan, released in August 2017, can be an important strategic tool to pressure Myanmar on the issue of creating an environment for the repatriation of refugees. The recent legal move by the Gambia in the International Court of Justice (ICJ) should be strongly supported by Bangladesh with OIC countries. Most importantly, Bangladesh should not only raise the problem in international forums but should speed up its diplomatic apparatus with the big players, namely, India, China, Russia and Japan, to pressure Myanmar, carefully balancing the interests of the major powers to achieve the successful repatriation of the Rohingya refugees.

Data availability The data supporting the study findings are available from the corresponding author on request.

\section{Declarations}

Conflict of interest No potential conflict of interest was reported by the author.

\section{References}

Agamben G (1998) Homo sacer: sovereign power and bare life. Stanford University Press, Stanford Ahmed A (2012) Bangladesh blames Muslim Rohingyas for temple attacks. https://www.reuters.com/ article/us-bangladesh-temples/bangladesh-blames-muslim-rohingyas-for-temple-attacks-idUSB RE8900CZ20121001 
Ahmed I (2010) The plight of the stateless Rohingyas: responses of the state, society \& the international community. The University Press Limited (UPL), Dhaka

Al Jazeera (2020) First Rohingya refugee dies from coronavirus in Bangladesh. Al Jazeera. https:// www.aljazeera.com/news/2020/06/rohingya-refugee-dies-coronavirus-bangladesh-camps-20060 2095409310.html

Ansar A (2020) The unfolding of belonging, exclusion and exile: a reflection on the history of Rohingya refugee crisis in Southeast Asia. J Muslim Minor Aff 40:441-456

Arendt H (2005) The origins of totalitarianism, 1st edn. Schocken Books, New York

Bangladesh Today (2016) China's \$24 billion boost to Bangladesh, a year after India gave \$2 billion. Bangladesh Today. https://www.indiatoday.in/world/story/china-bangladesh-24-billion-dollarboost-after-india-xi-jinping-346476-2016-10-14

Bangladesh Today (2019) Saudi Arabia deporting scores of Rohingya refugees to Bangladesh. Bangladesh Today. https://www.indiatoday.in/india/story/saudi-arabia-deporting-scores-of-rohingyasto-bangladesh-1425064-2019-01-07

Bari S (2020) The Rohingya refugee crisis: a time bomb waiting to explode. Soc Chang 50:285-299. https://doi.org/10.1177/0049085719901038

Bashar I (2017) Exploitation of the Rohingya crisis by Jihadist groups: implications for Bangladesh's internal security. Current Terrorist Trends and Analysis 9:5-7. https://www.jstor.org/ stable/https://doi.org/10.2307/26351550

Beech H (2013, 01 July) The face of Buddhist terror. TIME magazine. http://content.time.com/time/ magazine/article/09171214600000.html

Benhabib S (2014) Human rights and the critique of 'humanitarian reason'. Reset Dialogues on Civilisations, 10 July

Bhattacharyya R (2021, 22 December) Bhasan Char: a new home for Rohingya refugees. The Diplomat. https://hediplomat.com/2020/12/bhasan-char-a-new-home-for-rohingya-refugees/

British Broadcasting Corporation (BBC) (2001) Bangladesh-Burma border clash. British Broadcasting Corporation. http://news.bbc.co.uk/2/hi/south_asia/1106521.stm

British Broadcasting Corporation (BBC) (2019) Rohingya crisis: rallies mark two years of exile in Bangladesh. British Broadcasting Corporation. https://www.bbc.com/news/world-asia-49464427

British Broadcasting Corporation (BBC) Bangla (2021) Rohingya: what does the move of Bhasan Char far away from Myanmar border signal? (in Bangla language). https://www.bbc.com/benga li/news-55862006

Burchill S (2005) The national interest in international relations theory. Palgrave Macmillan, Houndmills. https://doi.org/10.1057/9780230005778

Buzan B (1997) Rethinking security after the Cold War. Coop Confl 32:5-28

Chan E (n.d.) The Rohingya Muslims in Myanmar. Encyclopaedia Britannica. https:/www.britannica. com/topic/Rohingya-Muslims-in-Myanmar-The-2038356

Chan E, Chiu C, Chan G (2018) Medical and health risks associated with communicable diseases of Rohingya refugees in Bangladesh 2017. Int J Infect Dis 68:39-43. https://doi.org/10.1016/j.ijid. 2018.01.001

Cheesman N (2017) How in Myanmar "national races" came to surpass citizenship and exclude Rohingya. J Contemp Asia: Interpreting Communal Violence in Myanmar 47:461-483. https://doi. org/10.1080/00472336.2017.1297476

Ciorciari JD (2020, 10 February) The UN's top court ordered Myanmar to protect the Rohingya. Here's how that could matter. The Washington Post. https://www.washingtonpost.com/politics/ 2020/02/10/uns-top-court-ordered-myanmar-protect-rohingya-heres-how-that-can-matter/

Creswell JW (2012) Qualitative inquiry and research design: choosing among five approaches. SAGE Publications, Thousand Oaks, CA

Danish Immigration Service (2011) Rohingya refugees in Bangladesh and Thailand: fact finding mission to Bangladesh and Thailand. Copenhagen

DeGooyer S, Hunt A, Maxwell L, Moyn S (2018) The right to have rights. Verso

Dhaka Tribune (2018). At least 40 Rohingyas recruited by JMB. Dhaka Tribune. https://www.dhaka tribune.com/bangladesh/crime/2018/12/14/at-least-40-rohingyas-recruited-by-jmb

Dhaka Tribune (2019a) Are all Rohingyas converging on Bangladesh? Dhaka Tribune. https://www. dhakatribune.com/bangladesh/rohingya-crisis/2019/01/23/are-all-rohingyas-converging-onbangladesh 
Dhaka Tribune (2019b) No Rohingya turn up for repatriation. Dhaka Tribune. https://www.dhakatribu ne.com/bangladesh/rohingya-crisis/2019/08/22/no-rohingya-turn-up-for-repatriation-to-myanm ar

Dhaka Tribune (2020) Bangladesh disburses \$500,000 to OIC for Gambia'case over Rohingya genocide. Dhaka Tribune. https://www.dhakatribune.com/bangladesh/rohingya-crisis/2020/11/28/bangladeshdisburses-500-000-to-oic-over-rohingya-genocide-case

Dhaka Tribune (2021) Rohingyas want to return to Myanmar; happy with Bhasan Char facilities. Dhaka Tribune. https://www.dhakatribune.com/bangladesh/foreign-affairs/2021/04/03/rohingyas-want-toreturn-to-myanmar-happy-with-bhasan-char-facilities

Ejaz R (2019) Myanmar drama over Rohingya repatriation. Prothom Alo. https://en.prothomalo.com/ bangladesh/Myanmar-drama-over-Rohingya-repatriation

Farzana K (2017) Memories of Burmese Rohingya refugees: contested identity and belonging. Palgrave Macmillan

Forty Rights (2014) Policies of persecution: ending abusive state policies against Rohingya Muslims in Myanmar. https://www.fortifyrights.org/downloads/Policies_of_Persecution_Feb_25_Fortify_ Rights.pdf

Halperin S, Heath O (2012) Political research: methods and practical skills. Oxford University Press, UK

Hill DM (1989) Human rights and foreign policy: theoretical foundations. Human rights and foreign policy. Palgrave Macmillan, London, pp 3-20

Hossain A (2019) Rohingya crisis is creeping but money flow declining (in Bangla language). BBC Bangla. https://www.bbc.com/bengali/news-49458960

Human Rights Watch (2000a) Historical background. https://www.hrw.org/reports/2000/burma/burm0 05-01.htm

Human Rights Watch (2000b). Discrimination in Arakan. https://www.hrw.org/reports/2000/burma/ burm005-02.htm

Human Rights Watch (2013) All you can do is pray: crimes against humanity and ethnic cleansing of Rohingya Muslims in Burma's Arakan State. Human Rights Watch

Human Rights Watch (2019) Myanmar: events of 2018. https://www.hrw.org/world-report/2019/countrychapters/myanmar-burma\#619ec4

International Crisis Group (2018) Countering Jihadist militancy in Bangladesh. https://www.crisisgroup. org/asia/south-asia/bangladesh/295-countering-jihadist-militancy-bangladesh

International Crisis Group (2019) Situation report: Rohingya crisis. https://www.humanitarianresponse. info/sites/www.humanitarianresponse.info/files/documents/files/sitrep_june_2019_final.pdf

Islam SS (2007) State terrorism in Arakan. In: Tan ATH (ed) A handbook of terrorism and insurgency in Southeast Asia. Edward Elgar, Cheltenham, pp 325-351

Kasai T (2019) Japan's cold-blooded approach to the Rohingya crisis. Japan Times. https://www.japan times.co.jp/opinion/2019/06/27/commentary/japan-commentary/japans-cold-blooded-approachrohingya-crisis/\#.Xt_bty-cZQJ

Khan MT, Ahmed S (2019) Dealing with the Rohingya crisis: the relevance of the general assembly and R2P. Asian J Comp Politics. https://doi.org/10.1177/2057891119868312

Kingston L (2013) A forgotten human rights crisis: statelessness and issue (non)emergence. Hum Rights Rev 14:73-87. https://doi.org/10.1007/s12142-013-0264-4

Kipgen N (2019) The Rohingya crisis: the centrality of identity and citizenship. J Muslim Minor Aff 39:61-74. https://doi.org/10.1080/13602004.2019.1575019

Lewis D (2019) Humanitarianism, civil society and the Rohingya refugee crisis in Bangladesh. Third World Q: Special issue: Citizen aid and everyday humanitarianism. In: Fechter A-M, Schwittay A (Guest Eds) 40:1884-1902. https://doi.org/10.1080/01436597.2019.1652897

Liton S (2018) Rohingya repatriation: a pipe dream? The Daily Star. https://www.thedailystar.net/front page/mayanmar-refugee-crisis-rohingya-repatriation-pipe-dream-1497811

Lutz-Auras L (2015) Russia and Myanmar-friends in need? J Curr Southeast Asian Aff 34:165-198

Maclean K (2019) The Rohingya crisis and the practices of erasure. J Genocide Res 21:83-95. https://doi. org/10.1080/14623528.2018.1506628

Mathieson DS (2009) Plight of the damned: Burma's Rohingya. Global Asia, A Journal of the East Asian Foundation. www.globalasia.org. 4

Morgenthau HJ (1993) Politics among nations: the struggle for power and peace. McGraw-Hill, Boston

Palma P (2019) Repatriation bids: designed to fail. The Daily Star. https://www.thedailystar.net/front page/news/repatriation-bids-designed-fail-all-along-1790116 
Panda A (2019) Will Myanmar's navy get its first submarine from the Indian Navy? The Myanmar Navy is moving toward a submarine capability with India's assistance. The Diplomat. https://thediplomat. com/2019/07/will-myanmars-navy-get-its-first-submarine-from-the-indian-navy/

Ragland T (1994) Burma's Rohingyas in crisis: protection of "humanitarian" refugees under international law. B C Third World L J 14:301-336

Rahman U (2010) The Rohingya refugee: a security dilemma for Bangladesh. J Immigr Refug Stud 8:233-239

Riaz A (2019) Voting in a hybrid regime: explaining the 2018 Bangladeshi election. Palgrave Macmillan, Singapore

Riley A, Varner A, Ventevogel P, Taimur Hasan M, Welton-Mitchell C (2017) Daily stressors, trauma exposure, and mental health among stateless Rohingya refugees in Bangladesh. Transcult Psychiatry 54:304-331. https://doi.org/10.1177/1363461517705571

Rüland A (2017) Myanmar's Rohingya problem in context. Institut für Strategie- Politik- Sicherheits- und Wirtschaftsberatung (ISPSW) Strategy Series

Solomon F (2019) 'We're not allowed to dream' Rohingya Muslims exiled to Bangladesh are stuck in limbo without an end in sight. TIME magazine. https://time.com/longform/rohingya-muslims-exilebangladesh/?fbclid=IwAR268hVoeFB2H2V4UAvy2Q8xUxG03mHeuxkipirt3IE6kMv3R5qWPJx $\mathrm{CpNc}$

Taufiq HA (2019) China, India, and Myanmar: playing Rohingya roulette? In: Hussain I (ed) South Asia in global power rivalry: inside-out appraisals from Bangladesh. Palgrave Macmillan, Singapore

Thawnghmung AM (2014) Contending approaches to communal violence in Rakhine State. In: Gravers M, Ytzen F (eds) Burma/Myanmar-where now? Nias Press. p 330

The Daily Star (2017) Rohingya repatriation: Is Bangladesh falling for Myanmar's ploy? The Daily Star. https://www.thedailystar.net/opinion/perspective/rohingya-repatriation-1482733

The Daily Star (2018) Killing of Rohingyas: Death toll could be up to 25,000. The Daily Star. https:// www.thedailystar.net/news/frontpage/killing-rohingyas-death-toll-could-be-over-10000-1622392

The Daily Star (2019a) No-man's land: Myanmar building concrete structure. The Daily Star. https:// www.thedailystar.net/rohingya-crisis/news/myanmar-building-concrete-structure-no-mans-land1686436

The Daily Star (2019b) Repatriation of the Rohingyas: all an eye-wash. The Daily Star. https://www.theda ilystar.net/star-weekend/news/repatriation-the-rohingyas-all-eye-wash-1788433

The Daily Star (2019c) Rohingya crisis: Japan eager to play mediator. The Daily Star. https://www.theda ilystar.net/politics/news/rohingya-crisis-japan-eager-play-mediator-1779244

The Daily Star (2019d) Rohingya influx caused reduction of wages in host community. The Daily Star. https://www.thedailystar.net/city/news/rohingya-influx-caused-reduction-wages-host-communityreport-1776967

The Daily Star (2020) CPD projects only 2.5\% GDP growth for Bangladesh, lowest in 25 years. The Daily Star. https://www.thedailystar.net/business/cpd-projects-only-2.5-percent-gdp-growth-forbangladesh-1910421

The Guardian (2008) Bangladesh and Burma send warships into Bay of Bengal. The Guardian. https:// www.theguardian.com/world/2008/nov/04/bangladesh-burma

The Guardian (2016) China and Russia oppose UN resolution on Rohingya. The Guardian. https://www. theguardian.com/world/2017/dec/24/china-russia-oppose-un-resolution-myanmar-rohingya-musli ms?fbclid=IwAR3Xns5EeqWyzWdcQ-nbBw-iYkKiz17fvzAMJu9JAC9STbiASqywmw_EKP8\# maincontent

The Guardian (2019) Rohingya refugees turn down second Myanmar repatriation effort. The Guardian. https://www.theguardian.com/world/2019/aug/22/rohingya-refugees-turn-down-second-myanmarrepatriation-effort

The Times of India (2016) Bangladesh buys two submarines from China. The Times of India. https:// timesofindia.indiatimes.com/world/south-asia/Bangladesh-buys-two-submarines-from-China/artic leshow/55415904.cms

The Voice of America (VOA) (2019) Gambia sues Myanmar for genocide against Rohingya Muslims. The Voice of America. https:/www.voanews.com/africa/gambia-sues-myanmar-genocide-againstrohingya-muslims

The Washington Post (2018) How the Rohingya crisis is affecting Bangladesh — and why it matters. The Washington Post. https://www.washingtonpost.com/news/monkey-cage/wp/2018/02/12/how-therohingya-crisis-is-affecting-bangladesh-and-why-it-matters/ 
The Washington Post (2019) North Korea, China and Russia are arming Myanmar's military, UN report finds. The Washington Post. https://www.washingtonpost.com/world/asia_pacific/north-koreachina-and-russia-are-arming-myanmars-military-despite-genocide-accusations-un-report-finds/ 2019/08/05/f4dd49d0-b531-11e9-acc8-1d847bacca73_story.html

United Nations (UN) (1998) The Universal Declaration of Human Rights, 1948-1998. United Nations Dept. of Public Information, New York

United Nations (UN) (2017) UN human rights chief points to 'textbook example of ethnic cleansing' in Myanmar. UN News. https://news.un.org/en/story/2017/09/564622-un-human-rights-chief-pointstextbook-example-ethnic-cleansing-myanmar

United Nations (UN) (2018) One year into the Rohingya crisis. Office of the Special Representative on Sexual Violence in Conflict. https://www.un.org/sexualviolenceinconflict/press-release/one-yearinto-the-rohingya-crisis-special-representative-patten-calls-for-accountability-for-sexual-viole nce-crimes/

United News of Bangladesh (UNB) (2019). Bangladesh needs 'internationalisation' of Rohingya issue in stronger way. http://unb.com.bd/category/Special/bangladesh-needs-internationalisation-of-rohin gya-issue-in-stronger-way/26719

United Nations High Commissioner for Refugees (UNHCR) (1951) States parties, including reservations and declarations, to the 1951 Refugee Convention. https://www.unhcr.org/5d9ed32b4

United Nations High Commissioner for Refugees (UNHCR) (2015) UNHCR Global Appeal 2014-2015: Myanmar. https://www.unhcr.org/en-my/528a0a32b.pdf

United Nations High Commissioner for Refugees (UNHCR) (2018a) Bangladesh refugee emergency factsheet - protection. https://data2.unhcr.org/en/documents/download/67748

United Nations High Commissioner for Refugees (UNHCR) (2018b) Rohingya refugee crisis: learn the facts. https://www.unrefugees.org/news/rohingya-refugee-crisis-learn-the-facts/

United Nations High Commissioner for Refugees (UNHCR) (2019). World's biggest refugee settlement gets biggest ever waste facility. https://www.unhcr.org/news/briefing/2019/2/5c540fe74/worldsbiggest-refugee-settlement-gets-biggest-waste-facility.html

Villasana D (2017) Picturing health: Rohingya refugees in Bangladesh. The Lancet 390:2233-2242. https://doi.org/10.1016/S0140-6736(17)32862-3

Walt SM (2018) The world wants you to think like a realist. Foreign Policy. https://foreignpolicy.com/ 2018/05/30/the-world-wants-you-to-think-like-a-realist/

Waltz K (1988) The origins of war in neorealist theory. J Interdiscip Hist 18:615-628

Weissbrodt D, Collins C (2006) The human rights of stateless persons. Hum Rights Q 28:245-276. https://doi.org/10.1353/hrq.2006.0013

World Bank (2018a) Bangladesh: reducing poverty and sharing prosperity. https://www.worldbank.org/ en/results/2018/11/15/bangladesh-reducing-poverty-and-sharing-prosperity

World Bank (2018b) Enhancing opportunities for clean and resilient growth in urban Bangladesh: country environmental analysis 2018. http://documents.worldbank.org/curated/en/585301536851966 118/pdf/129915-CEA-P161076-PUBLIC-Disclosed-9-16-2018.pdf 